\title{
A COMPARATIVE ECONOMIC ANALYSIS OF SALT TOLERANT BINADHAN-8 AND BR-28 RICE PRODUCTION IN SATKHIRA DISTRICT OF BANGLADESH
}

\author{
K. A. Kana ${ }^{1}$, M. H. A. Rashid ${ }^{2}$, M. M. Islam ${ }^{3}$ and M. A. Baree ${ }^{4}$ \\ Department of Agricultural Economics, Bangladesh Agricultural University \\ Mymensingh-2202, Bangladesh
}

\begin{abstract}
This study was conducted to compare the profitability of salt tolerant Binadhan-8 and BR-28 production in coastal Satkhira district of Bangladesh. Thirty salt tolerant Binadhan- 8 producing farmers were purposively selected since the introduction of this paddy is new in that area. Another 30 BR-28 producing farmers were selected randomly from the farmers' list obtained from the Upazila Agriculture Office. Data were collected using pre-tested structured questionnaires. Cost and return analysis as well as functional analysis were performed in this study. The results of the study revealed that per hectare total cost for Binadhan- 8 was higher than BR-28 rice. Taking the production into account the total return of Binadhan- 8 per hectare was higher than the total return of BR-28 rice per hectare. The sample farmer appeared to have used seeds, Urea, TSP, MP, etc. at less than the required level. Regression analysis suggests that the Binadhan- 8 rice growers should limit the use of power tiller and insecticide. Contribution of these inputs to the two varieties was found to be positive but at decreasing rate for BR-28 and at increasing rate for Binadhan-8.
\end{abstract}

Key Words: Salinity, Salt tolerant, Rice, Profitability

\section{INTRODUCTION}

Bangladesh is a south Asian country with an area of 147570 sq. km. Bangladesh borders India on three sides, north, east, west and the Bay of Bengal on the south. The population of Bangladesh is about 150 million, of which 25 million live in the coastal districts. The density of population in the coastal districts is higher than that of the rest of the country. The density of population has increased as much as four times during this century (BBS, 2009). The high rate of population growth pushes millions of people to live in the low lying coastal areas which are highly vulnerable to various types of environmental hazards. The Bangladesh coast is the most hazardous coast in the world in terms of the number of

1 Ex-postgraduate student, 2Professor, Department of Agricultural Economics, Bangladesh Agricultural University, Mymensingh-2202, Bangladesh

3 SSO, BINA, Mymensingh, Bangladesh

4 Associate Professor, Department of Crop Science \& Technology, University of Rajshahi, Rajshahi, Bangladesh 
people who suffer from various types of environmental hazards every year. The coastal cyclonic surges are the most dangerous hazards in the coastal areas of Bangladesh. When the annual cyclones roar in, hundreds and sometimes thousands of people are swept away. Flooding has become a common annual hazard during the rainy season in recent years. There are about 300 large rivers, creeks, and channels in Bangladesh forming a network together with the three major rivers, the Ganges, the Bramhaputra, and the Meghna. The dimensions of these rivers and their drainage basins are disproportionately large compared to the small area of Bangladesh. Seasonal variation in precipitation and in the intensity and amount of discharge causes the flood flow in Bangladesh. Changes in the base level of the rivers due to sea level rise have added another dimension to the flooding problem. Now, compared to past, the same amount of water can cause intensive flooding in the country. The annual flood situation, especially in the low lying coastal districts, has further deteriorated following the damming, Farakka barrage, of the Ganges inside India. The drainage capability of the Ganges and its distributaries has been reduced due to the increase in aggradations of river beds since the diversion of the upstream flow of the Ganges. Now, less water flows from India into Bangladesh during times of drought, in summer months, and more is released during flood season which causes severe flooding, such as in 1974, 1987, and in 1988. Salinity is common in arid and semi arid region, especially scarcity of water and the hot dry climates frequently cause salinity intrusions that limit or prevent high crop production. Irrigation is also a common cause by which agricultural land is degraded, as salt dissolved in the irrigation water is left in the soil following evapo-transpriation. In the present, salinity is the second most widespread soil problem in rice growing countries next to drought and considers as a serious constraint to increased rice production worldwide (Gergorio et al., 1997). In Bangladesh, saline soil covers about 1.0 million hectares of land (BBS, 2004). The total saline area forms one third of the 9 million hectares of total national cultivated area of Bangladesh (ABSPII, 2006). Salinity is the most common problem of Bangladesh. In Bangladesh, over $32 \%$ of the net cultivated areas in our costal and off shore area which is equivalent to 0.83 million hectare that constitute about $53 \%$ of the cultivable area in 13 districts of the South-east part. This area is largely affected by varying degrees of soil salinity. Agricultural land uses in there areas are vary poor and cropping intensity is very low (62\% only) where the country average cropping intensity is 190\% (Kabir, 2007). Daily two high tide and two low tide result in saline water of this area. As the flow of fresh water is low in this area, salinity of water in increasing day by day. Salinity problem received very little attention in the past, but due to increased demand for growing more food to feed the booming population of the country, it has become imperative to explore the potentials of these lands. The effective reclamation of the saline soils is difficult and complex due to frequent inundation and tidal flooding. It could be, therefore, wise to grow the salt tolerant cultivars of rice in the coastal area or for localities where salinity is increasing due to effect of Farakka barrage or due to addition at low quality irrigation water. During dry season the ground water level goes down and salinity increases. The national policy is to develop same rice cultivars that will be adopted in this region for increasing the production of rice. So far, no promising salinity tolerant rice cultivar had been developed for this saline area. Thus this vast land remains fallow and un productive during Boro and Aus seasons. Therefore development salt tolerant rice cultivars is highly demanding to enhance the national production of rice. 
Agriculture is a major sector of Bangladesh's economy and the coastal area of Bangladesh is very fertile for growing rice. Increase in salinity intrusion and increase in soil salinity will have serious negative impacts on agriculture. The food production does not seem to have a better future in the event of a climate change. In Bangladesh, rice production may fall by $10 \%$ and wheat by 30\% 2050 (IPCC, 2007). In Bangladesh, saline soil covers about 1.0 million hectares of land. The existing modern varieties are not adapted to this ecosystem because of their lack of salt tolerance and water logging in many areas. But now it becomes an essential for us to adapt modern varieties under saline environment. It is clear from the above that salinity has become an ever escalating threat to food security in the coastal areas of Bangladesh. Salinity, among other natural hazards, has pushed the costal people to acute food insecurity in the recent years. Introduction of salinity tolerant rice varieties in the coastal area of Bangladesh would be an effective way of increasing crop production. These areas are potentially suited for rice production but were left idle because of salinity problem. Having conceived this, Bangladesh Institute of Nuclear Agriculture (BINA) introduced a new salt tolerant rice variety, Binadhan-8 in the coastal areas of Bangladesh which showed an impressive result in different areas of the country in Boro season. An economic study on the profitability and adaptability of this saline tolerant rice variety is of utmost importance. With this end in view, the present study was undertaken to :

i. To determine the profitability of Binadhan-8 and BR-28;

ii. To assess the factors affecting production of Binadhan-8 and BR-28; and

iii. To suggest policy guidelines/recommendations.

\section{METHODOLOGY}

\section{The data and sampling technique}

The study was undertaken in Satkhira sadar Upazila of Satkhira district, the southwest part of the country. Sampling technique was used to select representative farmers to minimize time and cost of the study. For the study, at first a list of the farmers who produced either Binadhan-8 or BR-28 was collected from Upazila Agriculture Office. From that list, 30 Binadhan- 8 producing farmers were selected purposively and 30 BR-28 producing farmers were selected randomly. In addition, some relevant information was also collected from a group of well-to-do farmers with economic solvency. Boro season generally begins in January- February and ends in mid April and May. To satisfy the objectives of the study, data on the profitability of Binadhan- 8 and BR-28 were collected during the Boro season of 2011 using survey method. Both primary and secondary were used in this study.

\section{Analytical techniques used}

Conventional statistical tools like average, percentages, ratio etc. were applied to arrive at meaningful findings in this study. Cost and return analysis was done using the following profit equation.

$$
\Pi=\sum \mathrm{P}_{\mathrm{m}} \mathrm{Q}_{\mathrm{m}}-\sum\left(\mathrm{P}_{\mathrm{xi}} \mathrm{X}_{\mathrm{i}}\right)-\mathrm{TFC}
$$


Where,

$$
\begin{aligned}
& \Pi=\text { Net return }(\mathrm{Tk} / \mathrm{ha}) ; \\
& P_{\mathrm{m}}=\text { Per unit price of produce }(\mathrm{Tk} / \mathrm{kg}) ; \\
& Q_{\mathrm{m}}=\text { Quantity of the production per hectare }(\mathrm{kg}) ; \\
& P_{x i}=\text { Per unit price of } \mathrm{i} \text { th inputs }(\mathrm{Tk}) ; \\
& X_{\mathrm{i}}=\text { Quantity of the } \mathrm{i}^{\text {th }} \text { inputs per hectare }(\mathrm{kg}) ; \\
& \text { TFC = Total fixed cost (Tk); and } \\
& \mathrm{i}=1,2,3, \ldots \ldots \ldots \ldots \ldots . ., \mathrm{n} \text { ( number of inputs). }
\end{aligned}
$$

Undiscounted benefit cost ratio (BCR) was used to compare the profitability of Binadhan-8 and BR-28 rice. Cobb-Douglas production function was used to estimate the effects of various inputs for the production of Binadhan -8 and $B R-28$ because of the best fit of the sample data. The functional form of the Cob-Douglas multiple regression equation was as follows:

$Y_{i}=\mathrm{aX}_{1}{ }^{\mathrm{b} 1} \mathrm{X}_{2}^{\mathrm{b} 2} \mathrm{X}_{3}^{\mathrm{b} 3} \mathrm{X}^{\mathrm{b} 4} \mathrm{X}_{5}^{\mathrm{b} 5} \mathrm{X}_{6}^{\mathrm{b} 6} \mathrm{e}^{\mathrm{u}}$

The equation may be alternatively expressed as log-linear form:

$$
\ln Y_{i}=\ln a+b_{1} \ln X_{1_{i}}+b_{2} \ln X_{2_{i}}+b_{3} \ln _{3_{i}}+b_{4} \ln X_{4_{i}}+b_{5} \ln X_{5_{i}}+b_{6} \ln X_{6_{i}}+U_{i}
$$

Where, $Y_{i}=$ Gross return (Tk/ha); ln a = Intercept or constant term; $X_{1}=$ Human labour $\operatorname{cost}(\mathrm{Tk} / \mathrm{ha}) ; \mathrm{X}_{2}=$ Animal labour/power tiller cost $(\mathrm{Tk} / \mathrm{ha}) ; \mathrm{X}_{3}=$ Seed/seedling cost $(\mathrm{Tk} / \mathrm{ha}) ; \mathrm{X}_{4}=$ Cost of fertilizer $(\mathrm{Tk} / \mathrm{ha}) ; \mathrm{X}_{6}=$ Insecticide cost $(\mathrm{Tk} / \mathrm{ha}) ; \mathrm{b}_{1}, \mathrm{~b}_{2},---------, \mathrm{b}_{6}=$ Coefficients of the respective variables; $\mathrm{U}_{\mathrm{i}}=$ Error term; $\mathrm{ln}=$ Natural logarithm; e = Base of natural logarithm; and $i=1,2,3, \ldots, 30$.

\section{RESULTS AND DISCUSSION}

Every production process needs some costs i.e. variable and fixed cost. Land rent and interest on operating capital were considered as fixed cost. Human labour, seed, power tiller, fertilizer, insecticides, irrigation and manures were considered as variable cost. For better comparative analysis, input use pattern was furnished separately for Binadhan- 8 and BR-28 as presented in Table 1.

\section{Cost of human labor}

Human labor is the most important input for producing Binadhan- 8 and BR-28. The operation wise distribution of human labour indicated that, the highest proportion of human labour cost was employed for harvesting (1352.08 Tk./ha for BR-28 and 2311.63 Tk./ha for Binadhan-8, respectively) while transplanting cost constituted the second highest $1274.45 \mathrm{Tk} /$ ha proportion for BR-28 and 2177.61 Tk./ha for Binadhan-8, respectively. The total cost of human labour for Binadhan- 8 and BR-28 was estimated at Tk. 12629.08 and Tk.7221.67 per hectare, respectively (Table 1). 


\section{Cost of seed}

Seed is the basic input for crop production. The costs of seed for BR-28 and Binadhan- 8 were Tk. 992.49 and Tk. 1979.49 per hectare which was respectively 4.21 percent and 4.84 percent of total variable cost. Hence, it was clear that per hectare seed cost was relatively much higher for Binadhan-8 rice production than that of BR-28 rice production.

Table 1. Pre hectare operation-wise distribution of human labour requirement for Binadhan- 8 and BR-28 rice production

\begin{tabular}{l|cc|c|c}
\hline \multirow{2}{*}{ Operation } & \multicolumn{2}{c|}{ BR-28 } & \multicolumn{2}{c}{ Binadhan-8 } \\
\cline { 2 - 5 } & Cost Tk/ha & \% of total cost & Cost Tk/ha & \% total cost \\
\hline Land preparation & 1179.89 & 16.33 & 2028.65 & 16.06 \\
Transplanting & 1274.45 & 17.64 & 2177.61 & 17.24 \\
Weeding & 632.71 & 8.76 & 1242.34 & 9.83 \\
Fertilizer & 527.95 & 7.31 & 1057.19 & 8.07 \\
Insecticide & 395.12 & 5.47 & 765.97 & 6.16 \\
Harvesting & 1352.08 & 18.72 & 2311.63 & 18.30 \\
Threshing & 977.51 & 13.53 & 1593.17 & 12.61 \\
Drying and Cleaning & 881.93 & 12.21 & 1452.49 & 11.50 \\
\hline Total & 7221.67 & 100.00 & 12629.08 & 100.00 \\
\hline
\end{tabular}

Source: Field survey, 2011

\section{Cost of fertilizers}

Both the BR-28 and Binadhan- 8 rice producers used the following types of fertilizers available such as Urea, TSP, MP, cow dung and Zinc sulphate. Total fertilizer cost for producing BR-28 was estimated at Tk. 6674.20 and for Binadhan-8, was estimated at Tk. 11264.85 per hectare (Table 2).

\section{Cost of power tiller}

Power tiller was mainly used for land preparation and is some cases for carrying and threshing of harvested crops (Table 1). The power tiller also reduced the cost for tillage operation. Per hectare power tillage cash cost for land operation of BR-28 was estimated at Tk. 975.02 and Tk. 1878.45 for Biandhan-8 rice production (Table 2).

\section{Cost of insecticides}

Both the BR-28 and Binadhan-8 rice growers used insecticide to protect their crops from pest attack. They used insecticides like Furadon, Dimecron, Bashudin, Sumitheon, Ronster etc. In the study area per hectare insecticide costs were Tk. 137.44 and Tk. 209.95 for BR-28 and Binadhan- 8 respectively which was 0.58 percent and 0.51 percent of the total variable input cost (Table 2). 


\section{Cost of irrigation}

In the study area, all the sample farmers used irrigation water from Shallow Tube-well (STW) for producing BR-28 and Binadhan-8 rice. It was found that the in the study area irrigation cost was high because for salinity land need so most irrigation. For irrigation coat of BR-28 was estimated at Tk.7569.91 and Binadhan-8 was Tk. 12925.50 respectively. This represented 32.11 percent and 31.61of percent of the total material input cost for BR28 and Binadhan-8 respectively (Table 2 ).

Table 2. Per hectare costs of BR-28 and Binadhan- 8 rice production (on full cost basis)

\begin{tabular}{|c|c|c|c|c|}
\hline \multirow[t]{2}{*}{ Items of cost } & \multicolumn{2}{|c|}{ BR-28 } & \multicolumn{2}{|c|}{ Binadhan-8 } \\
\hline & Cost (Tk/ha) & $\%$ of total cost & Cost (Tk/ha) & $\%$ of total cost \\
\hline \multicolumn{5}{|l|}{ A. Variable cost } \\
\hline Human labour & 7221.67 & 30.63 & 12629.08 & 30.88 \\
\hline Power tiller & 975.02 & 4.13 & 1878.45 & 4.59 \\
\hline Seed & 992.49 & 4.21 & 1979.49 & 4.84 \\
\hline \multicolumn{5}{|l|}{ Fertilizer } \\
\hline Urea & 4490.90 & 19.05 & 7011.61 & 17.14 \\
\hline TSP & 841.03 & 3.56 & 1565.45 & 3.82 \\
\hline $\mathrm{MP}$ & 302.60 & 1.36 & 673.87 & 1.65 \\
\hline Zinc Sulphate & 92.16 & 0.39 & 190.26 & 0.46 \\
\hline Cow dung & 929.49 & 3.94 & 1823.63 & 4.46 \\
\hline Insecticide & 137.44 & 0.58 & 209.95 & 0.51 \\
\hline Irrigation & 7569.91 & 32.11 & 12925.50 & 31.61 \\
\hline A. Total Variable cost & 23571.01 & 100.00 & 40887.33 & 100.00 \\
\hline \multicolumn{5}{|l|}{ B. Fixed cost } \\
\hline Land used cost & 14969.69 & 95.50 & 7484.84 & 85.92 \\
\hline $\begin{array}{l}\text { Interest on operating capital } \\
@ 12 \% \text { for } 6 \text { months }\end{array}$ & 737.12 & 4.69 & 1226.61 & 14.08 \\
\hline B. Total fixed cost & 15706.81 & 100.00 & 8711.45 & 100.00 \\
\hline Total cost $(A+B)$ & 39277.82 & & 49598.78 & \\
\hline
\end{tabular}

Source: Field survey, 2011

\section{Interest on operating capital}

Interest on operating capital which includes variable costs in the production of BR-28 and Binadhan-8 were calculated for a period of 6 months production period. Interest rate of 12 percent per annum for both varieties was considered for calculation. An average interest on operating capital was estimated at Tk.737.12/ha for BR-28 and Tk.1226.61/ha for Binadhan-8 respectively, which were $4.69 \%$ and $7.57 \%$ of the total fixed cost in producing both the enterprises, respectively (Table 2). 


\section{Land use cost}

In the study area, most of the farmers had own land for producing BR-28 and Binadhan- 8 rice. The seasonal rental cost of land was treated as land use cost for the farmers. Land use cost was a fixed cost for the producers. Table 2 shows that per hectare land use cost amounted to Tk. 14969.69 for BR-28 and Tk. 7484.84 for Binadhan-8 rice respectively (Table 2).

\section{Total cost}

In order to estimate the average total cost per hectare, all the resources used in rice production as said earlier have been recaptured together. This analysis revealed that per hectare total cost of production of Binadhan- 8 rice was higher than that of production BR28. BR-28 rice growers incurred Tk. 39277.82/ha and Binadhan-8 rice farmers spent Tk.49598.78/ ha for rice production respectively (Table 2).

\section{Total returns (TR)}

Per hectare total returns were calculated by multiplying the total amount of product and by-product with their respective market prices. Thus, it was clear that per hectare yield of Binadhan- 8 was much higher than BR-28 rice. Table 3 shows that per hectare values of main product of BR-28 and Binadhan-8 were Tk. 91892.88 and Tk. 117681.8, respectively. Taking the by product value into account the total returns were Tk. 95837.88 and Tk. 122012.8 per hectare for BR-28 and Binadhan- 8 rice respectively which is significantly different. Thus, it was clear that Binadhan- 8 earned higher gross return than that of BR-28 rice producers.

\section{Gross margin (GM)}

It is known that gross margin is the difference of total variable cost from total return. Per hectare gross margin of both the enterprises was obtained by deducting total variable cost from total return. Per hectare gross margin of Binadhan-8 rice was estimated at Tk. $81125.47 /$ ha and for BR-28, it was Tk. 72266.81/ha. So, it was impressive from the results the gross margin of Binadhan- 8 rice was greater than that of BR-28 (Table 4 ).

Table 3. Yield and return per hectare of BR-28 and Binadhan-8 rice production

\begin{tabular}{lcccc}
\hline \multicolumn{1}{c}{ Particulars } & Units & BR-28 & Binadhan-8 \\
\hline Main product & $\mathrm{kg}$ & 4836.46 & 5884.09 \\
Price & $\mathrm{Tk} / \mathrm{kg}$ & 19 & 20 \\
Value & $\mathrm{Tk}$. & 91892.88 & 117681.8 \\
By-product & $\mathrm{kg}$ & 3945 & 4331 \\
Price & $\mathrm{Tk} / \mathrm{kg}$ & 1.00 & 1.00 \\
Value & $\mathrm{Tk}$. & 3945.00 & 4331.00 \\
\hline Total return & $\mathrm{Tk}$. & 95837.88 & 122012.8
\end{tabular}

Source: Field survey, 2011 
Table 4. Gross margin of Binadhan-8 and BR-28 rice production (per hectare)

\begin{tabular}{|c|c|c|}
\hline Items & BR-28 & Binadhan-8 \\
\hline Total return (Tk/ha) & 95837.82 & 122012.8 \\
\hline Total variable cost (Tk/ha) & 23571.01 & 40887.33 \\
\hline Gross margin (Tk/ha) & 72266.81 & 81125.47 \\
\hline
\end{tabular}

\section{Net return (NR)}

Net return is a useful tool to evaluate the business profitability or financial solvency of any kind of agribusiness. It was estimated by deducting total cost from total return. Per hectare net return of BR-28 rice was lower than that of Binadhan-8 rice. Per hectare net returns of Binadhan-8 rice was Tk. 72414.02/ha while it was Tk. 56560.00/ha for BR-28 rice (Table 5).

\section{Benefit cost ratio (BCR)}

Table 5 shows that benefit cost ratio (undiscounted) of BR-28 and Binadhan- 8 rice production was emerged as 2.44 and 2.46, respectively implying that Tk. 2.44 and Tk. 2.46 would be earned by investing every Tk. 1.00 in BR-28 and Binadhan- 8 rice production (Table 5). Table 5 revealed that benefit cost ratio (2.46) of Binadhan-8 rice production was higher compared to that of BR-28 rice indicating that investment in Binadhan-8 rice production would be more profitable.

Table 5. Per hectare net return of Binadhan- 8 and BR-28 rice production

\begin{tabular}{lcc}
\hline \multicolumn{1}{c|}{ Items } & BR-28 & Binadhan-8 \\
\hline Total Returns(Tk/ha) & 95837.82 & 122012.8 \\
Total cost (Tk/ha) & 39277.82 & 49598.78 \\
Net return (Tk/ha) & 56560.00 & 72414.02 \\
BCR (Undiscounted) & 2.44 & 2.46 \\
\hline
\end{tabular}

\section{Contribution of different inputs to Binadhan-8 and BR-28 production}

Rice output elasticity coefficients for human labour cost, power tiller cost and insecticide cost in case of Binadhan- 8 production were found to be positive and significant. This showed that increase in the use of these inputs would result an increase in efficiency of Binadhan-8 production contributing significantly towards gross return. In case of BR-8 rice, production elasticity of human labour cost, seed cost, irrigation cost and insecticide cost was positive and significant. The coefficients of human labour cost, power tiller cost and insecticide cost were 0.302, 0.312 and 0.257, respectively in case of Binadhan-8 production. This indicates that keeping other factors constant, return from Binadhan-8 production would increase by $0.302,0.312$ and 0.257 percent, respectively with 1 percent increase in the use of these inputs. In case of BR-28, the co-efficient of human labour cost, seed cost, irrigation cost and insecticide cost are $0.399,0.7020 .430$ and 0.589 , respectively which are positive and significant. This indicates that keeping other factors constant, 
return from BR-28 rice production would increase by $0.399,0.7020 .430$ and 0.589 , respectively if the these inputs were individually increased by 1 percent (Table 6).

The coefficient of multiple determination $\left(\mathrm{R}^{2}\right)$ tells how well the sample regression line fits the data (Gujarati, 1995). It is evident from Table 6 that the values of $R^{2}$ are 0.746 and 0.709 for Binadhan- 8 and BR-28 rice, respectively. This mean that around 75 and 71 percent of the variations in gross return for Binadhan -8 and BR-28 rice, respectively were explained by the independent variables included in the model. The sum of elasticity coefficients was 1.088 in case of Binadhan-8 meaning increasing returns to scale and 0.937 in case of BR-28 rice meaning decreasing returns to scale. This means that, 1 percent increase in all inputs simultaneously would result on average 1.088 and 0.937 percent increase in gross return of Binadhan -8 and BR-28 rice, respectively.

Table 6. Estimated values of regression coefficients and related statistics of Cobb-douglas revenue type production function for Binadhan -8 and BR-28 rice production

\begin{tabular}{l|c|c|c|c}
\hline \multirow{2}{*}{ Explanatory variables } & \multicolumn{2}{c|}{ Binadhan-8 } & \multicolumn{2}{c}{ BR-28 } \\
\cline { 2 - 5 } & $\begin{array}{c}\text { Estimated } \\
\text { values }\end{array}$ & $\begin{array}{c}\text { Standard } \\
\text { error }\end{array}$ & $\begin{array}{c}\text { Estimated } \\
\text { values }\end{array}$ & $\begin{array}{c}\text { Standard } \\
\text { error }\end{array}$ \\
\hline Intercept & 2.363 & - & 2.528 & - \\
Human labour cost $\left(\mathrm{X}_{1}\right)$ & $0.302^{* *}$ & 0.119 & $0.399^{* *}$ & 0.186 \\
Power tiller cost $\left(\mathrm{X}_{2}\right)$ & $0.312^{* * *}$ & 0.084 & 0.059 & 0.626 \\
Seed cost $\left(\mathrm{X}_{3}\right)$ & 0.230 & 0.160 & $0.702^{* * *}$ & 0.248 \\
Fertilizer cost $\left(\mathrm{X}_{4}\right)$ & 0.092 & 0.141 & 0.054 & 0.120 \\
Irrigation cost $\left(\mathrm{X}_{5}\right)$ & 0.079 & 0.122 & $0.430^{* *}$ & 0.198 \\
Insecticides cost $\left(\mathrm{X}_{6}\right)$ & $0.257^{* *}$ & 0.109 & $0.589^{* * *}$ & 0.161 \\
F-value $(\mathrm{N}=30)$ & \multicolumn{2}{c}{11.238} & \multicolumn{2}{c}{9.336} \\
Coefficient of multiple determination $\left(\mathrm{R}^{2}\right)$ & \multicolumn{2}{c}{0.746} & \multicolumn{2}{c}{0.709} \\
Returns to scale $\left(\Sigma \mathrm{b}_{\mathrm{i}}\right)$ & \multicolumn{2}{c}{1.088} & \multicolumn{2}{c}{0.937} \\
\hline
\end{tabular}

Note: ${ }^{* * *}$ significant at 1 percent and ${ }^{* *}$ significant at 5 percent level

\section{CONCLUSION AND RECOMMENDATIONS}

The economy of Bangladesh mainly depends on agriculture. Agriculture plays a vital role in the growth and stability of the country's economy. Rice is the main item of food for the people of this country. On the basis of seasonal classification, three types of rice are grown in Bangladesh namely- Aus, Aman and Boro rice comprised the largest portion of the total rice production of the country. Economic development largely depends on the agricultural development which is possible only through distribution and utilization of modern technology, such as, hybrid seeds, power tiller, tractor, chemical fertilizers, pesticides, irrigation etc. A comprehensive study incorporating impact of technological change on 
farmer's income and poverty alleviation was important. Some studies have so far focused on the comparative performance of Binadhan- 8 and BR-28 rice.

The results of the present study showed that cultivation of both salt tolerant Binadhan- 8 and BR-28 were highly profitable from the viewpoint of individual farmers. Cultivation of Binadhan- 8 was more profitable compared to BR- 8 . The study identified some problems in Biandhan-8 and BR-28 rice production. Some major problems faced by the farmers were: problems of seed purity, seed collection, low germination rate, grain unfilling, high grain falling, problem of high price of seed, lack of knowledge of new salt tolerant rice varieties, lack of marking facilities etc. The problems were found to be more acute for the production of BR-28 rice compared to Binadhan- 8 rice. Though, both the varieties were found profitable, Binadhan- 8 rice was found more profitable than BR-28 rice variety with respect to yield, net revenue and gross revenue. Since the introduction of salt tolerant Binadhan -8 has shown greater profit compared to BR-28 rice, it should be justified to bring more and more areas under this new rice variety cultivation, which in turn will help to achieve self-sufficiency in food grains and thus to promote the better living standard of the coastal people of Bangladesh than ever before.

\section{REFERENCES}

ABSPII (Agricultural Biotechnology Support Project II), 2006. Drought tolerant rice and salinity tolerance rice. Agricultural Biotechnology Support Project II-South Asia, 26 p.

BBS, 2009. Statistical Year Book of Bangladesh , Bangladesh Bureau of Statistics, Ministry of Planning ,Government of the People's Republic of Bangladesh, Dhaka.

Gregorio, G. B., Senadhira, D. and Mendoza, R. D. 1997. Screening rice for salinity tolerance. IRRI Discussion Paper Series No. 22. Manila (Philippines): International Rice Research Institute. pp. 1-30.

Gujarati, D. N. 1995. Basic Econometrics. Third Edition, New York, McGraw Hill Kogakusha Ltd.

Kabir, S. A. M. 1970. "Comparative Economic study of the Production of IR-8 and Local Varieties of Rice in Boro Season Low-Lift Power Pump Irrigation in Tow Villages of Mymensingh District." Master's degree thesis, submitted to the Department of Agricultural Economics, Bangladesh Agricultural University, Mymensingh. 